This is an Accepted Manuscript of an article published by Taylor \& Francis in Climate Policy on 21/03/2018, available online:

http://www.tandfonline.com/doiffull/10.1080/14693062.2018.1450724

\title{
Financing loss and damage: Reviewing options under the Warsaw International Mechanism
}

Jonathan Gewirtzman. Climate and Development Lab, Brown University, 85 Waterman Street, Providence, RI 02906 USA. +1 401-863-5152. jonathan_gewirtzman@alumni.brown.edu.

Sujay Natson. Environmental Change Institute, School of Geography and the Environment, University of Oxford, South Parks Road, Oxford, OX1 3QY, UK. Tel: +44 1865285070. sujay_natson@alumni.brown.edu.

Julie-Anne Richards. Independent Consultant, Olympic House, 12 Somerford Grove, London, N16 7TY. UK. +44 7500747674. jar@jarclimate.net.

Victoria Hoffmeister. Climate and Development Lab, Brown University, 85 Waterman Street, Providence, RI 02906 USA. +1 401-863-5152. victoria_hoffmeister@alumni.brown.edu.

Alexis Durand. Institut d'études politiques de Paris, 27 Rue Saint-Guillaume, 75007 Paris, France.. +3306239637 92. Alexis.durand@sciencespo.fr.

Romain Weikmans. Centre for Studies on Sustainable Development, Institute for Environmental Management and Land-use Planning, Université Libre de Bruxelles / Free University of Brussels, Av. F.D. Roosevelt 50 CP130/03, 1050 Ixelles, Belgium. romain.weikmans@ulb.ac.be

Saleemul Huq. International Centre for Climate Change and Development (ICCCAD). Independent University, Bangladesh, Plot 16 Block B, Aftabuddin Ahmed Road, Bashundhara R/A, Dhaka, Bangladesh. +880 127975 4662. saleemul.huq@iied.org.

J. Timmons Roberts. Climate and Development Lab \& Institute at Brown for Environment and Society, Brown University, 85 Waterman Street, Providence, RI 02906 USA. +1 401-863-5152. Timmons@brown.edu.*Corresponding author 


\section{Financing loss and damage: Reviewing options under the Warsaw International Mechanism}

Abstract: After decades of pressure from vulnerable developing countries, the Warsaw International Mechanism on Loss and Damage (the WIM) was established at the nineteenth Conference of the Parties (COP 19) in 2013 to address costly damages from climate change. However, little progress has been made towards establishing a mechanism to fund loss and damage. The WIM's Executive Committee issued its first two-year workplan the following year at COP 20 which offered, among other things, a range of approaches to financing loss and damage programmes, which we review here. We provide brief overviews of each mechanism proposed by the WIM ExCom, describe their current applications, their statuses under the UNFCCC, some of their advantages and disadvantages, and their current or potential application to loss and damage. We find that several of these mechanisms may be useful in supporting loss and damage programmes, but identify three major gaps. First, most of the mechanisms identified by the WIM ExCom are insurance schemes subsidized with voluntary contributions, which may not be adequate or reliable over time. Second, none were devised to apply to slow-onset events, or to non-economic losses and damages. That is, if harms are to parts of a society or its ecosystems that have no price, or if they occur gradually, they would probably not be covered by these mechanisms. Finally, the lack of a dedicated and adequate flow of finance to address the real loss and damage being experienced by vulnerable nations will require the use of innovative financial tools beyond those mentioned in the WIM ExCom workplan.

\section{Key policy insights}

- Despite a full article of the 2015 Paris Agreement devoted to loss and damage, there is little international agreement on the scope of loss and damage programmes, and especially how they would be funded and by whom.

- Most of the loss and damage funding mechanisms identified by the WIM ExCom are insurance schemes subsidized with voluntary contributions, which may burden the most vulnerable countries and may not be reliable over time.

- None of the mechanisms were devised to apply to slow-onset events, or to non-economic losses and damages.

Policy Relevance Statement: After years of arguments by developing countries for recognition of loss and damage (beyond their ability to adapt to climate impacts), a full article of the 2015 Paris Agreement was devoted to the issue. International mechanisms to address loss and damage are receiving increased attention, particularly given the intensification of climate impacts occurring and projected to occur in the coming years, and the inability of mitigation and 
adaptation projects to adequately address those impacts. However, there is little international agreement on the scope of loss and damage programs, and especially how they would be funded and by whom. As such, it is crucial to identify potential funding sources and assess their efficacy, reliability, and equity, so that loss and damage response programs can be institutionalized, implemented, evaluated and improved.

Word Count: 4852

Keywords: loss and damage, UNFCCC, climate finance, insurance and risk, Warsaw International Mechanism, least developed countries (LDCs) 


\section{Financing loss and damage: Reviewing options under the Warsaw International Mechanism}

\section{Introduction}

As climate change impacts escalate and emissions continue to rise, pressure to support vulnerable states' responses to climate-related "loss and damage" through the United Nations Framework Convention on Climate Change (UNFCCC) has intensified. Loss and damage is commonly understood to refer to irreversible losses (e.g. loss of life, species, land) and costly damages (e.g. destroyed infrastructure) associated with the adverse impacts of climate change. The issue is gaining attention in academic and policy circles due to increasingly obvious shortfalls in mitigation action and adaptation support. However, there exists little understanding and agreement on how support for loss and damage efforts would be funded, and by whom. Without a reliable stream of loss and damage funding, hard-won recognition for the issue could be a hollow victory for vulnerable countries across the globe.

The topic of loss and damage first emerged in international climate negotiations as early as 1991, when Vanuatu, speaking on behalf of the Alliance of Small Island States (AOSIS), proposed an international insurance pool to compensate small island developing states for damages from rising sea levels (Vanhala and Hestbaek, 2016). However, it was only at the $19^{\text {th }}$ Conference of the Parties (COP 19) in 2013 that Parties agreed to establish institutional arrangements on loss and damage, creating the Warsaw International Mechanism for Loss and Damage (WIM). This development was perceived as a major victory for the many vulnerable country Parties that had argued for years for such institutional arrangements. At COP 20 in 2014, Parties adopted an initial two-year workplan for the WIM Executive Committee (WIM ExCom), establishing an exploratory direction. This initial workplan, however, has been criticised for focusing primarily on the first two elements of the WIM mandate - knowledge-gathering activities and coordination of bodies already working on relevant issues - and neglecting the third element, enhancing action and support, including finance (Richards and Schalatek, 2017; CAN and BOND, 2017).

The devotion of a full article to loss and damage in the 2015 Paris Agreement was an unprecedented acknowledgement of the issue's significance, although still with limitations. Article 8 of the Agreement states that "Parties should enhance understanding, action and support, including through the Warsaw International Mechanism, as appropriate, on a cooperative and facilitative basis" for loss and damage (UNFCCC, 2015, Art. 8.3). Decision 1/CP.21, which provides details for implementation of the Paris Agreement, constrains potential loss and damage finance under Article 8 by stating that the article "does not involve or provide a basis for any liability or compensation" (UNFCCC, 2015, Decision 1/CP.21, para. 51). Opportunities for ratcheting up support for loss and damage are also limited by the fact that the Paris Agreement does not mention loss and damage in its finance article, or call for loss and damage to be included in the Agreement's enhanced transparency framework (van Asselt et al., 2016), 
including the global stocktake process (Sharma, 2017).

This restrained approach was perpetuated in the WIM's five-year workplan, which was adopted in 2017 at COP 23 (UNFCCC, 2017a). The five-year workplan includes only a strategic workstream on "enhanced cooperation and facilitation," rather than providing for new sources of finance (UNFCCC, 2017b). Calls from the Least Developed Countries Group for inclusion of loss and damage as a standing item on the subsidiary bodies' agenda (LDC Group, 2017) were only partially recognized. Higher-level political discussions of loss and damage, including finance options, were postponed to an "expert dialogue" in 2018, which will aim only to inform a technical paper commissioned at COP 22 as an input to the 2019 review of the Warsaw International Mechanism (UNFCCC, 2017a).

Parties have signalled the need for support, including financial support, to prevent and address loss and damage. Estimates of loss and damage costs and "adequate" financial support for loss and damage vary considerably. The Climate Vulnerable Forum and DARA (a Spanish NGO), for example, estimate that developing countries could face a loss of US $\$ 4$ trillion per year by 2030, and least developed countries would face the largest damages proportionate to the size of their economies (McKinnon, 2012). Baarsch et al. (2015) estimate that loss and damage in developing countries could be US $\$ 400$ billon per year by 2030 and US $\$ 1$ trillion per year by 2050 if warming remains below $2^{\circ} \mathrm{C}$, and substantially more if warming increases to $3^{\circ} \mathrm{C}$. On this basis, Richards and Schalatek (2017) recommend a goal of providing at least \$200-300 billion per year by 2030 for loss and damage.

This paper aims to enhance understanding of the existing options for financing loss and damage currently under consideration by the UNFCCC, by reviewing the approaches mentioned in the initial two-year workplan for the WIM Executive Committee. ${ }^{1}$ The focus of this initial list was on insurance mechanisms, rainy-day funds, and bonds. For each instrument, we provide a concise description and discuss its current applications, its status under the UNFCCC, some of its advantages and disadvantages, and its potential applications to loss and damage. After reviewing and explaining these approaches, we identify two key gaps: the workplan focuses on voluntary contributions to insurance schemes and lacks attention to instruments which would apply to slow-onset events and/or non-economic loss and damage. Finally, we conclude that the lack of a dedicated and adequate flow of finance to address loss and damage requires innovative approaches, an issue we take up elsewhere (Roberts et al., 2017).

\section{Financing loss and damage: A review of approaches proposed by the WIM ExCom}

An understanding of the Warsaw International Mechanism Executive Committee's (WIM ExCom's) list of approaches is fundamental to analysing the potential ways forward on financing

\footnotetext{
${ }^{1}$ Our review originated as a response to a call for submissions from the WIM Executive Committee (Durand, 2016; for a summary of those submissions, refer to UNFCCC, 2016).
} 
climate change-related losses and damages. The decision establishing the WIM describes the ExCom's mandate as to "enhance action and support, including finance" for loss and damage (Decision 2/CP.19 UNFCCC, 2013). The decision includes calls to "enhance," "facilitate," "mobilise," or "provide" finance or resources on five occasions. The intent to generate and disperse additional finance for loss and damage is clear. However, negotiators have manoeuvred this initial mandate through a series of non-transparent steps ${ }^{2}$ towards a focus on "financial instruments," and almost exclusively on market-based, private sector instruments.

Within the loss and damage context, market instruments can be distinguished from solidarity instruments based on whether a population at risk or the international community assumes the bulk of fiscal responsibility. In general, market instruments place responsibility directly on the communities at risk, for example, by expecting them to pay an insurance premium, whereas solidarity instruments transfer responsibility to the international community, including nations with greater historical responsibility for emissions (UNFCCC, 2008). Gradually and over time, solidarity-based proposals, including public sector interventions, taxation, and transfers from developed nations to vulnerable countries, have been downplayed, whilst private sector insurance-type interventions have been given a central role. This shift from the original mandate was noted by panellists and audience members at a side event held by the ExCom in November 2017 (ExCom, 2017). The shift first appeared in changing language between the initial mandate in Decision 2/CP.19 and Action Area 7 of the ExCom's two-year workplan, which aims to encourage "the diffusion of information related to financial instruments and tools." While submissions made in response to this Action Area included public finance and non-market approaches (CAN, 2016; CARE, 2016; Durand et. al, 2016), the resulting summary report (UNFCCC, 2016) focused on private sector, market-based options.

Here, we consider the range of approaches mentioned in the initial two-year workplan for the WIM ExCom. The ExCom's list of financial instruments to be investigated consists of "comprehensive risk management capacity with risk pooling and transfer; catastrophe risk insurance; contingency finance; climate-themed bonds and their certification; catastrophe bonds; and financing approaches to making development climate resilient" (UNFCCC Secretariat, 2014). We review each of the instruments identified by the ExCom in turn below.

\subsection{Comprehensive risk management capacity with risk pooling and transfer}

Insurance allows the transfer of risk from the initial risk holders to the insurer, allowing risk holders to pass some of their high-risk exposure, for a premium, to actors with relatively stable and much broader financial bases. Risk pooling enables the aggregation of risk over larger

\footnotetext{
${ }^{2}$ Virtually all negotiations on loss and damage are held behind closed doors at COPs, and at the ExCom meeting to formulate the five-year workplan, all negotiations on the five-year workplan were held in closed sessions, excluding representatives of observer organizations.
} 
geographical areas. If climate risk is aggregated, severe climate-related losses and damages in certain locales may be offset by lower costs in other areas. Moreover, vulnerable countries can benefit from lowered premiums as insurers take into account the risk profile across countries in the pool, rather than only an individual country's risk profile. An example of a regional risk pool that allows countries to insure their liabilities at a lower cost is the African Risk Capacity facility, a sovereign-level climate risk and disaster response insurance pool currently insuring six African countries against drought (African Risk Capacity, 2017). Aggregation of risk also allows disaster-stricken areas to access collective reserves when necessary and to "gain catastrophe insurance on better terms" (Warner et al., 2009). We discuss catastrophe risk insurance in greater detail in the following section.

Insurance penetration in developing countries remains low. In poor countries, on average, only two percent of total losses due to weather-related events are insured (Hoeppe, 2016). In recognition of this coverage gap, the decision adopting the Paris Agreement requested that the WIM ExCom "establish a clearinghouse for risk transfer that serves as a repository for information on insurance and risk transfer" to facilitate Parties' efforts to improve their risk management (UNFCCC, 2015, Paragraph 49). A clearinghouse was duly established in November 2017 at COP 23 (Fiji Clearing House for Risk Transfer, 2017). However, to date, contributions from developed countries to insurance has been ad hoc, and developing countries still bear most of the financial burden in risk transfer schemes (Estrin and Tan, 2016).

There are several potential drawbacks to placing insurance mechanisms at the centre of climate risk management efforts. First, if highly vulnerable countries, rather than nations bearing the greatest responsibility for climate change, must shoulder the burden of paying their own insurance premiums, issues of equity arise. Second, premiums may be prohibitively expensive for poor countries, and payouts may prove insufficient to address losses and damages (Reeves, 2017; World Bank, 2017). Third, as climate events increase in frequency, intensity, and predictability and related premiums rise, the viability of insurance mechanisms as an approach to widespread loss and damage will diminish. Finally, some critics of insurance approaches for managing climate risk have warned of a 'moral hazard' effect, arguing that insurance may provide a sense of security that attenuates incentives for risk reduction (Hudson et al., 2014). For example, in the short term, insurance coverage could encourage development, farming, or other activities in high-risk areas likely to experience catastrophic impacts in the future. However, those most affected by loss and damage impacts, particularly communities in least developed countries, may be unable to pursue some risk reduction efforts, regardless of whether insurance coverage provides temporary relief (UNEP 2016).

Where insurance mechanisms are appropriate, it is crucial to consider how risk insurance can be integrated with risk reduction efforts and embedded in a comprehensive risk management strategy, thereby averting a 'moral hazard' effect (Hoeppe, 2016). Creating an "operational link between risk transfer and risk reduction" is essential to promoting adaptive responses while 
preparing for impacts (Surminski and Oramas-Dorta, 2014). Therefore, policymakers should consider including complementary risk reduction approaches in risk transfer mechanisms. They can do so by encouraging or requiring insurers to promote risk reduction, by means of discounted rates for effectively reduced risks. Insurers can also enhance the quality of pre-disaster risk assessments, and thereby aid government risk planning, by improving the pricing accuracy of premiums (Hoeppe, 2016).

Conventional insurance is best suited for unpredictable, rapid-onset events, and it is considered unsuitable for foreseeable, slow-onset events (Warner et al., 2013). Some scholarship has considered innovative risk transfer approaches that would surpass the constraints of conventional insurance to apply to slow-onset events (e.g. Kehinde, 2014). Parametric insurance schemes, for instance, redefine the trigger event that would prompt a payout. Such schemes can be triggered by parameters relevant to slow-onset events, like annual temperature rise or sea level rise (Kehinde, 2014). Parametric insurance is discussed in more depth below.

\subsection{Catastrophe risk insurance}

Catastrophe risk insurance is a specific type of risk transfer, defined as insurance coverage for low-probability, high-cost disasters, with payouts occurring when some set of indicators is achieved. Catastrophe risk insurance may take a variety of forms, triggered by indicators at the micro, meso, or macro level. For example, parametric insurance schemes prompt payouts when large-scale climate conditions or impacts exceed defined thresholds (Blampied, 2016). Insurance may be distributed on a micro scale to, for example, smallholder farmers, and can also be matched with meso- or macro-design by national governments or sub-national organisations. If risk insurance contracts cover a sufficiently large area and are designed to incentivise risk reduction activities, such as using drought resistant crops, then they can also positively impact regional gross domestic product (Warner et al., 2009; Hoeppe, 2016).

A few multi-country catastrophe risk insurance schemes are already in operation. The Caribbean Catastrophe Risk Insurance Facility (CCRIF) was the first multi-country catastrophe risk insurance instrument. Formed in 2007, the CCRIF draws upon a regional fund jointly financed by Caribbean governments, allowing the CCRIF to respond promptly to hurricanes and earthquakes and limit their economic impacts by providing financial liquidity for participants (Caribbean Catastrophe Risk Insurance Facility, 2017). Since 2015, the CCRIF has expanded to include Central American countries, and 17 countries are currently members. From its launch through mid-2017, CCRIF had made 36 payouts totalling about US\$120 million to 13 members under their tropical cyclone, excess rainfall, and earthquake policies (Caribank, 2017).

Index-based or parametric schemes define specific parameters prompting payouts, possibly allowing for payouts based on triggers related to slow-onset events. The African Risk Capacity 
Insurance Company recently employed this technique to expand coverage to apply to long-term droughts (Wilcox et al., 2014). However, this application of risk insurance requires high-quality catastrophe risk models that can be expensive to create and difficult to employ. For example, the African Risk Capacity initiative has been accused of applying an inadequate model to famine conditions in Malawi, resulting in a late and insufficient payout (Reeves, 2017). ${ }^{3}$ Overall, in spite of a few notable efforts to apply insurance schemes to slow-onset climate events, risk insurance is generally not considered an optimal tool to address loss and damage from high-frequency or slow-onset disasters with a high certainty of occurrence (Munich Climate Insurance Initiative, 2012).

\subsection{Contingency finance}

"Contingency finance" refers to the common practice of including extra "rainy day funds" in project budgets to prepare for the possibility of cost overruns or unforeseen circumstances (European Commission, 1998). Some institutions have already adopted this approach to prepare for climate-related disasters, stockpiling funds for emergency situations and integrating this financial planning with other comprehensive risk management strategies. The Bangladesh Climate Change Trust Fund is a prominent example of a contingency fund applied to climate impacts. The fund is maintained by the Bangladeshi government to finance climate-related projects, with about 34 percent of the annual endowment set aside for "emergencies" (Khan, Huq, and Shamsuddoha, 2012). ${ }^{4}$ Contingency finance encourages disaster planning by making predictable the availability of post-disaster funds. However, determining adequate fund reserves in the face of uncertainty about the types, frequencies, and intensities of climate disasters can be a challenge.

Contingency finance, generally considered a public-sector option, can give institutions flexibility in disaster response. Setting aside contingency finance allows institutions to plan fund allocation in advance of disasters and then distribute finances earlier in the course of disasters, providing vulnerable households with assistance "at the crucial time of shock, before they resort to livelihood-eroding coping mechanisms" (Makaudze, 2012). Contingency finance can also be included in individual program budgets to extend existing support mechanisms to more people during climate-related disasters. For example, Ethiopia's Productive Safety Net Programme continually provides basic aid to the chronically food insecure, but includes contingency funds in its budget for extending coverage to the temporarily food insecure in the event of a shock damaging agricultural productivity (Makaudze, 2012).

\footnotetext{
${ }^{3}$ The ARC model used the assumption that farmers would plant maize with maturation times of 120-140 days. However, 60 percent of maize planted by farmers had a maturation time of just 90 days. Therefore, the impact of the drought was much worse than anticipated, as rains came too late to water the maize seeds actually planted (Reeves 2017).

${ }^{4}$ National decision making in Bangladesh about when and how to release these funds was still ongoing at the time of this writing.
} 
Overall, contingency finance may contribute to better disaster planning and more prompt disaster response, as pools of money are designated before adverse climate impacts hit. However, by tying funds to specific types of impacts and response efforts, contingency finance may reduce flexibility in responses to unpredictable disasters. Furthermore, this mechanism places the onus on governments in vulnerable, less developed nations to set aside funds for contingency finance, leaving smaller budgets to address other pressing needs.

\subsection{Climate-themed bonds}

Climate bonds are debt securities used to finance projects linked to climate change mitigation or adaptation. They are mostly issued by corporations, state-owned utilities, and multilateral development banks. Purchasers are largely institutional investors. Purchase of climate bonds by central banks has been suggested to mobilize finance for the UNFCCC's Green Climate Fund, with the potential to raise sums larger than the US\$100 billion annual global financing goal for 2020 that was established at COP 15, held in Copenhagen in 2009 (Kroll, 2015). Bonds are also becoming increasingly available for purchase by individuals.

End uses of climate-related bond finance (and, more broadly, green bond finance) have been subject to criticism. Shishlov et al. (2016) note that further efforts must be made to ensure the environmental integrity of green bonds beyond current certification efforts. Currently, the green bond market lacks explicit and shared objectives for green bond standards, which may result in accusations of greenwashing or increased transaction costs. In addition, as standards are developed, the pipeline of available climate-friendly projects should be expanded through strategies such as reducing the cost of capital (Shishlov, Morel, and Cochran, 2016).

The concept of bonds for mitigation projects being repaid with the revenue that cleaner and more efficient energy, industry, transportation, or agriculture generates is straightforward. However, greater uncertainty lies in how climate bonds could be used to finance loss and damage-related projects. Climate bonds can serve as an attractive long-term investment instrument in areas where significant returns for purchasers are foreseeable. However, it is unclear how this condition could be met in the context of loss and damage. Still, there is the possibility that green bonds can support adaptation and mitigation projects that could prevent loss and damage. Creative developments in the catastrophe bond market, which we differentiate from the climate bond market, have yielded more relevant products, as discussed next.

\subsection{Catastrophe bonds}

Whereas climate-themed bonds are issued to raise capital for climate-related projects, catastrophe (cat) bonds protect the bond issuer from catastrophic impacts by providing the issuer 
with funds if a catastrophe strikes (Lebens, 2013). Cat bonds are high-yield investments that involve a specific set of conditions, stating that if the bond issuer suffers from a certain predefined disaster, the issuer's obligation to pay interest and/or repay the principal to investors is either deferred or completely forgiven. Cat bonds may be issued by insurers to protect finances in the event of disaster, or by countries to ensure sufficient financing for disaster response. Alternatively, countries or insurance pools may purchase catastrophe bonds from subnational governments or communities in order to assume and dilute local risks. Several entities, including the CCRIF and the Turkish Catastrophe Insurance Pool have already employed cat bonds or are considering their use on a regional scale.

Cat bonds may be attractive to investors in that they are not closely linked to either stock markets or underlying economic conditions, and therefore allow diversification of portfolios and risks (Lebens, 2013). Additionally, the tool offers the security of collateralized protection; the entire reinsured amount is held in trust or invested securely. Moreover, the longer duration of cat bonds reduces "rollover" risk that arises when countries' maturing debt must be rolled over into new debt, raising the possibility of a higher interest rate (Lebens, 2013). Additionally, cat bonds do not require a mandatory reinstatement of the agreement if a loss occurs towards the end of the period, which is generally a condition in traditional reinsurance schemes.

The main shortfall of cat bonds is that they cover only sudden catastrophes, not slow-onset events. In addition, cat bonds tend to involve stricter terms and conditions than traditional insurance (Lebens, 2013). Cat bonds generally have a higher fixed cost, irrespective of how much is insured. Finally, cat bonds are often available only to institutional investors (Lebens, 2013).

Other innovative bond instruments tailored to climate change impacts are also being devised. For example, attribution bonds would cover the component of the probability of a natural disaster attributable to climate change, and sea level rise bonds would provide dividends in the event the mean sea level exceeds a predetermined threshold (Estrin and Tan, 2016). These bonds require extremely advanced modelling and currently exist only at the conceptual stage, but could be pursued in the future as sources of loss and damage finance.

\subsection{Other direct and indirect financing approaches}

The WIM two-year workplan includes a broad final category, described as "Financing approaches to making development climate resilient, among other innovative financial instruments and tools, both at the micro level (direct tools) and meso and macro level (indirect tools)." Under this category, Parties could consider innovative financial mechanisms such as a financial transaction tax, an international airline passenger levy, a solidarity levy, a bunker fuels levy, a fossil fuel levy, or a global carbon pricing system. We discuss these innovative 
mechanisms in depth elsewhere, concluding that some of them might raise substantial new funds to support loss and damage response efforts (see Roberts et al. 2017).

\section{Gaps and Directions: Conclusion}

We have reviewed the financial instruments to address climate-related loss and damage in developing countries listed in the initial two-year workplan for the Warsaw International Mechanism Executive Committee (the WIM ExCom). Our review indicates that a number of these instruments could viably contribute to effective support for loss and damage response efforts. Risk management approaches, including risk pooling, catastrophe risk insurance and catastrophe bonds, are clearly technically feasible, as they are already in use in some form in many developed and developing countries. Developed countries' recent pledges to support such mechanisms, and the popularity of applying risk management frames to loss and damage in the international climate policy sphere, suggest that such approaches may currently be the most politically feasible options available in the short term.

However, exclusive focus on risk transfer approaches is short-sighted. Without substantial external financial support lowering risk insurance premiums in vulnerable nations, private insurance remains largely unaffordable for households and small or medium-sized enterprises in highly exposed areas. Worryingly, the governments of the world's most vulnerable nations may be faced with a trade-off between the purchase of risk transfer instruments and government funding for other human needs (MCII, 2012). Therefore, the WIM ExCom must consider sources of finance to subsidise insurance as a risk transfer option in the face of loss and damage. In addition, risk transfer approaches will become more expensive and less viable as climate-related disasters occur more often and as slow-onset events increasingly manifest.

Crucially, the range of approaches to financing loss and damage response efforts listed in the initial two-year workplan for the WIM ExCom reviewed here display major gaps: almost none were devised to apply to slow-onset events or to non-economic loss and damage. Traditional insurance is designed to provide compensation for monetary damages triggered by sudden, unpredictable, and infrequent disasters. As climate change intensifies and disasters become more predictable and frequent, impacts will grow too certain and too costly to insure (Weingartner et al, 2017). Insurance is not well-suited to address slow-onset (and unrelenting) events such as sea level rise, desertification, and glacial melt. Instead, strategies to build community resilience, such as social protection schemes, livelihood diversification, and, in extreme cases, migration, will require loss and damage finance that is best provided by public sources. Finally, an insurancebased approach does not encompass an appropriate response to non-economic loss and damage. Risk insurance does not include any means to value or repay non-economic loss and damage, including loss of heritage, culture, languages, and ecosystems. 
Social and economic development concerns should be central in proposals to address loss and damage. Loss and damage approaches that integrate poverty reduction and other development strategies can better promote equitable, effective, and sustainable development. In addition, it must be ensured that the incorporation of loss and damage considerations into development projects, programmes and policies does not divert finance from other crucial climate-related initiatives and development objectives. In this regard, the mobilisation of new resources is critical. Research has suggested that existing resources for mitigation and adaptation have not been entirely "new and additional" (Weikmans and Roberts, 2017), as figures of climate finance have been bolstered by double-counted aid (Weikmans et al., 2017). The gaps between finance needed and provided and between finance counted and actually distributed for mitigation and adaptation is especially concerning in light of the volume of additional finance needed for loss and damage response, discussed further below.

In addition, developed countries' support for loss and damage response must not continue to almost exclusively take the form of one-time voluntary contributions to insurance schemes. Such pledges have been made on an ad hoc basis, without any long-lasting shift of the financial burden associated with risk insurance away from vulnerable country governments. Given this context, the InsuResilience Global Partnership on Climate and Disaster Risk Finance and Insurance Solutions, launched in 2015, is a development worthy of attention: the partnership has attracted pledges from G20 countries to support the provision of affordable insurance and other financial protection in the countries most vulnerable to climate change. Support from wealthy nations should be sustained, predictable, and adequate, and must increase steadily as climate change intensifies. The goal of at least $\$ 200-300$ billion per year by 2030 from Richards \& Schalatek (2017) points to the scale required.

A major gap remains between the amount of funding needed to support responses to loss and damage, including those described in this paper, and the amount of funding currently available. Most climate finance is directed towards mitigation efforts, rather than towards adaptation (AdaptationWatch, 2015; UNFCCC SCF, 2016). Despite a lack of measurement of loss and damage finance, we can assume that even less finance is directed towards efforts to address it. Loss and damage is an issue distinct from adaptation, and is therefore in serious need of distinct financial support. Future UNFCCC discussions and negotiations, including the scheduled 2019 review of the WIM, must consider establishing permanent, equitable, and adequate financial mechanisms for loss and damage. To deliver finance at the scale of losses and damages from climate change in vulnerable nations, innovative mechanisms for raising funding, such as levies on airline travel, fossil fuel extraction, greenhouse gas production, bunker fuel use, or financial transaction taxes - which have been overlooked by the WIM ExCom to date - must be urgently considered (Roberts et al. 2017). 


\begin{tabular}{|c|c|c|c|c|}
\hline & $\begin{array}{l}\text { Who } \\
\text { provides } \\
\text { payouts? }\end{array}$ & $\begin{array}{l}\text { Is there a } \\
\text { clear link to } \\
\text { loss and } \\
\text { damage? }\end{array}$ & $\begin{array}{l}\text { Useful for slow-onset } \\
\text { events and non- } \\
\text { economic loss and } \\
\text { damage (NELD)? }\end{array}$ & $\begin{array}{l}\text { What are possible } \\
\text { indirect effects? }\end{array}$ \\
\hline $\begin{array}{l}\text { (1) Risk } \\
\text { pooling and } \\
\text { transfer, } \\
\text { including (2) } \\
\text { catastrophe } \\
\text { risk } \\
\text { insurance }\end{array}$ & Private & $\begin{array}{l}\text { Yes, pays } \\
\text { when climate } \\
\text { catastrophe } \\
\text { strikes }\end{array}$ & $\begin{array}{l}\text { Not as typically applied } \\
\text { up to present: collect } \\
\text { payout when sudden } \\
\text { disaster strikes } \\
\text { unpredictably. } \\
\text { Parametric schemes } \\
\text { have been used sparsely } \\
\text { for slow-onset events. } \\
\text { In theory could apply to } \\
\text { NELD, but no standard } \\
\text { method yet exists to } \\
\text { quantify NELD }\end{array}$ & $\begin{array}{l}\text { Improves risk } \\
\text { assessments, provides } \\
\text { faster disaster response } \\
\text { since payout is } \\
\text { immediate, lowers } \\
\text { premiums if risk is } \\
\text { pooled, incentivises } \\
\text { adaptation }\end{array}$ \\
\hline $\begin{array}{l}(3) \\
\text { Contingency } \\
\text { finance }\end{array}$ & Public & $\begin{array}{l}\text { Yes, pays } \\
\text { when climate } \\
\text { catastrophe } \\
\text { strikes }\end{array}$ & $\begin{array}{l}\text { Not as applied up to } \\
\text { present: triggered only } \\
\text { in event of sudden } \\
\text { disaster }\end{array}$ & $\begin{array}{l}\text { Improves risk planning } \\
\text { since budget is certain, } \\
\text { funds are held in reserve } \\
\text { at expense of other } \\
\text { government programmes }\end{array}$ \\
\hline $\begin{array}{l}\text { (4) Climate- } \\
\text { themed } \\
\text { bonds }\end{array}$ & $\begin{array}{l}\text { Mostly } \\
\text { private; } \\
\text { can be } \\
\text { public }\end{array}$ & $\begin{array}{l}\text { No, only } \\
\text { applied to } \\
\text { mitigation and } \\
\text { tenuously to } \\
\text { adaptation in } \\
\text { the past }\end{array}$ & $\begin{array}{l}\text { Application to loss and } \\
\text { damage, including } \\
\text { NELD and loss and } \\
\text { damage from slow- } \\
\text { onset events, is unclear }\end{array}$ & $\begin{array}{l}\text { Indirect effects are } \\
\text { unknown since } \\
\text { application to loss and } \\
\text { damage is unclear }\end{array}$ \\
\hline $\begin{array}{l}(5) \\
\text { Catastrophe } \\
\text { bonds }\end{array}$ & $\begin{array}{l}\text { Public } \\
\text { and } \\
\text { private }\end{array}$ & $\begin{array}{l}\text { Yes, pays } \\
\text { when climate } \\
\text { catastrophe } \\
\text { strikes }\end{array}$ & $\begin{array}{l}\text { Not as applied up to } \\
\text { present: loans only } \\
\text { forgiven in event of } \\
\text { sudden disaster }\end{array}$ & $\begin{array}{l}\text { Facilitates faster disaster } \\
\text { response, as response } \\
\text { funds are already held } \\
\text { and simply used when } \\
\text { needed }\end{array}$ \\
\hline
\end{tabular}




\section{References}

AdaptationWatch. (2015). Towards mutual accountability: The 2015 adaptation finance transparency gap report. Retrieved from: https://unfccc.int/files/cooperation_and_support/financial_mechanism/standing_committee/a pplication/pdf/aw_report_24_11_15_lo_res.pdf

African Risk Capacity (2017). How ARC works - African Risk Capacity. Retrieved from: http://www.africanriskcapacity.org/2016/10/29/how-arc-works/

Baarsch, Florent et al, Impacts of Low Aggregate INDCs Ambition, research commissioned by Oxfam, 2015. Retrieved from:

https://www.oxfam.org/sites/www.oxfam.org/files/file_attachments/rr-impacts-lowaggregate-indcs-ambition-251115-en.pdf

Blampied, Catherine (2016). Weathering a Risky Climate: The Role of Insurance in Reducing Vulnerability to Extreme Weather. Results UK. Retrieved from:

https://www.results.org.uk/sites/default/files/files/Weathering\%20a\%20Risky\%20Climate.pd f

CARE International (2016). CARE International submission on information on 'best practices, challenges and lessons learned from existing financial instruments at all levels that address the risk of loss and damage associated with the adverse effects of climate change'. Retrieved from:

http://unfccc.int/files/adaptation/groups_committees/loss_and_damage_executive_committee /application/pdf/care_submission_loss_and_damage_finance_(final_11_03_16).pdf

Caribank. (2017). Mexico and CDB approve USD14 mn grant to CCRIF SPC. Retrieved from: http://www.caribank.org/news/cdb-approves-usd14-mn-grant-to-ccrif-spc

Caribbean Catastrophe Risk Insurance Facility. (2017). About Us, CCRIF SPC. Retrieved from: http://www.ccrif.org/content/about-us

Climate Action Network (2016). Financial instruments to address loss and damage associated with the adverse effects of climate change : Best practices, challenges and lessons learned from existing financial instruments. Submission to the Executive Committee of the Warsaw International Mechanism on Loss and Damage. Retrieved from: http://unfccc.int/files/adaptation/groups_committees/loss_and_damage_executive_committee /application/pdf/can_submission_to_the_excom_of_the_wim_on_loss_and_damage_finance. pdf

Climate Action Network and BOND, (2017). Joint Submission on the Strategic Workstream on Loss and Damage Action and Support. February 2017. Retrieved from:

http://www.climatenetwork.org/sites/default/files/can_bond_joint_submission_on_the_strateg ic_workstream_on_loss_and_damage_finance.pdf

Durand, A., \& Huq, S. (2015). Defining loss and damage: Key challenges and considerations for developing an operational definition. Dhaka, Bangladesh: International Centre for Climate Change and Development. Retrieved from: http:/www.icccad.net/wpcontent/uploads/2015/08/Defininglossanddamage-Final.pdf

Durand, A., Hoffmeister, V., Roberts, J., Gewirtzman, J., Natson, S., Weikmans, R. and Huq, S. (2016). Financing Options for Loss and Damage: A Review and Roadmap. Unfccc.int. 
Retrieved from:

https://unfccc.int/files/adaptation/groups_committees/loss_and_damage_executive_committe e/application/pdf/browncdl-icccadfinancinglossanddamagepaperdraft.pdf

Estrin, D., \& Tan, S. V. (2016). Thinking outside the boat about climate change loss and damage: Innovative insurance, financial and institutional mechanisms to address climate harm beyond the limits of adaptation. Centre for International Governance Innovation. Retrieved from: https://www.cigionline.org/sites/default/files/workshop_washington_march2016.pdf

European Commission. (1998). Understanding and monitoring the cost-determining factors of infrastructure projects: A user's guide. Retrieved from: http://ec.europa.eu/regional_policy/sources/docgener/evaluation/pdf/5_full_en.pdf

Executive Committee of the Warsaw International Mechanism for Loss and Damage. Summary Note: Side Event Breaking New Ground: Risk Financing for Slow Onset Events. November 2017. Retrieved from:

http://unfccc.int/files/adaptation/groups_committees/loss_and_damage_executive_committee /application/pdf/side_event_summary_note.pdf

Fiji Clearing House for Risk Transfer. (2017). Home, Fiji Clearing House for Risk Transfer website. Retrieved from: http://unfccc-clearinghouse.org

Hallegatte, S., Vogt-Schilb, A., Bangalore, M. \& Rozenberg, J. (2017). Unbreakable: Building the Resilience of the Poor in the Face of Natural Disasters. Climate Change and Development. Washington, DC: World Bank. Retrieved from: https://openknowledge.worldbank.org/handle/10986/25335

Hoeppe, P. (2016). Climate risk insurance for the poor and vulnerable. Presentation, MCII Side Event: Insurance and Comprehensive Climate Risk Management. Bonn, Germany. Retrieved from: http://www.climateinsurance.org/fileadmin/mcii/documents/MCII_2016_CRI_for_the_Poor_and_Vulnerable_fu 11_study_lo-res.pdf

Hoffmeister, V., Averill, M., \& Huq, S. (2016, July). The role of universities in capacity building under the Paris Agreement (Policy Brief). Dhaka and Providence, RI: International Centre for Climate Change and Development \& Brown University's Climate and Development Lab. Retrieved from:https://www.brown.edu/academics/institute-environmentsociety/sites/brown.edu.academics.institute-environmentsociety/files/uploads/Capacity\%20Building\%20Policy\%20Brief\%20July\%204.pdf

Hudson, P., Botzen, W. J. W., Czajkowski, J., \& Kreibich, H. (2014). Risk selection and moral hazard in natural disaster insurance markets: Empirical evidence from Germany and the United States. Philadelphia, PA: Risk Management and Decision Processes Center. Retrieved from: http://opim.wharton .upenn.edu/risk/library/WP201407-Risk-Selection-in-Natural-DisasterInsurance-Markets.pdf.

Kehinde, B. (2014). Applicability of Risk Transfer Tools to Manage Loss and Damage from Slow-onset Climatic Risks. Procedia Economics and Finance, 18, 710-717. Retrieved from: https://www.sciencedirect.com/science/article/pii/S2212567114009940 
Khan, S.M.H., Huq, S. and Shamsuddoha, M. (2012) The Bangladesh National Climate Funds: A brief history and description of the Bangladesh Climate Change Trust Fund and the Bangladesh Climate Change Resilience Fund. LDC Paper Series, IIED and ECBI. Retrieved from: http://ldccc.org/ldc/documents/bangladeshnationalfund.pdf

Kroll, M. (2015). Financing the green climate fund. How central banks can contribute to staying below the $2^{\circ} \mathrm{C}$ benchmark by purchasing Green Climate Bonds (Future Finance Policy Brief, No. 1.). Retrieved from:

https://www.worldfuturecouncil.org/file/2016/01/WFC_2015_Financing_the_Green_Climate Fund_En.pdf

Least Developed Countries Group (2017). Statement by the Federal Democratic Republic of Ethiopia on behalf of the LDC Group, Joint opening session for COP23/CMP13/CMA1.2. Retrieved from: https://ldcclimate.files.wordpress.com/2012/05/joint-cop-cmp-cma-openingstatement-long-version.pdf

Lebens, J. (2013, November 4). Cat bonds cedant's perspective. CAS Annual Meeting. Retrieved from: https://www.casact.org/education/annual/2013/handouts\%5CPaper_2724_handout_1506_0.p df; http://www.uwiseismic.com/Downloads/Poster_CAT\%20Bonds.pdf

Makaudze, E. (2012). Weather index insurance for smallholder farmers in Africa: Lessons learnt and goals for the future. Stellenbosch, South Africa: African Sun Media. Retrieved from: http://scholar.sun.ac.za/bitstream/handle/10019.1/101886/9781919985466.pdf?sequence=1

McKinnon, Matthew, ed. Climate Vulnerability Monitor 2, 2nd edition, DARA and the Climate Vulnerable Forum, 2012, p25. Retrieved from: http://daraint.org/climatevulnerabilitymonitor/climate-vulnerability- monitor-2012/ report/

MCII (Munich Climate Insurance Initiative). (2012). Insurance solutions in the context of climate change-related loss and damage: Needs, gaps, and roles of the Convention in addressing loss and damage. Submission to the SBI Work Program on Loss and Damage. Retrieved from:Molk, P. (2015). The government's role in climate change insurance. Boston College Environmental Affairs Law Review. Retrieved from: http://ssrn.com/abstract=2702879

Reeves, J. (2017). The wrong model for resilience: How G7-backed drought insurance failed Malawi, and what we must learn from it. Action Aid UK. Retrieved from: http://www.actionaid.org/publications/wrong-model-resilience-how-g7-backed-droughtinsurance-failed-malawi-and-what-we-must-1

Richards, J., Schalatek, L. (2017). Financing Loss and Damage: A Look at Governance and Implementation Options. Heinrich Böll Stiftung North America. Retrieved from:

https://www.boell.de/sites/default/files/loss_and_damage_finance_paper_update_16_may_20 17.pdf

Roberts, J.T., S. Natson, V. Hoffmeister, A. Durand, R. Weikmans, J. Gewirtzman, and S. Huq. (2017). "How will we pay for Loss and Damage?" Ethics, Policy, and Environment. 20: 2: 208-226. Retrieved from: http://www.tandfonline.com/doi/abs/10.1080/21550085.2017.1342963

Sharma, Anju (2017). Precaution and post-caution in the Paris Agreement: adaptation, loss and 
damage and finance, Climate Policy, 17:1, 33-47. Retrieved from: http://www.tandfonline.com/doi/full/10.1080/14693062.2016.1213697

Shishlov, I., Morel, R., \& Cochran, I. (2016). Beyond transparency: Unlocking the full potential of green bonds. Institute for Climate Economics. Retrieved from:

http://www.i4ce.org/download/unlocking-the-potential-of-green-bonds/

Surminski, S., \& Oramas-Dorta, D. (2014). Flood insurance schemes and climate adaptation in developing countries. International Journal of Disaster Risk Reduction, 7, 154164. Retrieved from: http:/www.sciencedirect.com/science/article/pii/S2212420913000563

UNEP (United Nations Environment Programme). (2017). The Adaptation Gap Report 2016. Retrieved from: http://web.unep.org/adaptationgapreport/2016

UNFCCC (United Nations Framework Convention on Climate Change). (2008). Technical paper: Mechanisms to manage financial risks from direct impacts of climate change in developing countries, FCCC/TP/2008/9. Retrieved from: http://unfccc.int/resource/docs/2008/tp/09.pdf

UNFCCC (United Nations Framework Convention on Climate Change). (2011). Report of the Conference of the Parties on its seventeenth session, held in Durban from 28 November to 11 December 2011. Addendum Part Two: Action taken by the Conference of the Parties at its seventeenth session, FCCC/CP/2011/9/Add.1. Durban. Retrieved from: http://unfccc.int/resource/docs/2011/cop17/eng/09a02.pdf\#page=5

UNFCCC (United Nations Framework Convention on Climate Change). (2012). Report of the Conference of Parties on its eighteenth session, held in Doha from 26 November to 8 December 2012. Addendum Part two: Action taken by the Conference of the Parties at its eighteenth session, FCCC/CP/2012/8/Add.1. Paris. Retrieved from: http://unfccc.int/resource/docs/2012/cop18/eng/08a01.pdf\#page=21

UNFCCC (United Nations Framework Convention on Climate Change). (2015). Report of the Conference of the Parties on its twenty-first session, held in Paris from 30 November to 13 December 2015. Addendum Part two: Action taken by the Conference of the Parties at its twenty-first session, FCCC/CP/2015/10/Add.1. Paris. Retrieved from: UNFCCC. (2014). Report of the executive committee of the Warsaw International Mechanism for Loss and Damage associated with climate change impacts.

FCCC/SB/2014/4. Paris. Retrieved from: http://unfccc.int/resource/docs/2014/sb/eng/04.pdf

UNFCCC Executive Committee Of The Warsaw International Mechanism For Loss And Damage (2016). Best Practices, Challenges And Lessons Learned From Existing Financial Instruments At All Levels That Address The Risk Of Loss And Damage Associated With The Adverse Effects Of Climate Change. Retrieved from:

http://unfccc.int/files/adaptation/groups_committees/loss_and_damage_executive_committee /application/pdf/aa7_d_information_paper.pdf

United Nations Framework Convention on Climate Change. (2017a). Report of the Executive Committee of the Warsaw International Mechanism for Loss and Damage associated with Climate Change Impacts. Draft conclusions proposed by the Chair/ Recommendation of the Subsidiary Body for Scientific and Technological Advice and the Subsidiary Body for Implementation. FCCC/FCCC/SB/2017/L.5. Retrieved from: http://unfccc.int/resource/docs/2017/sb/eng/105.pdf 
United Nations Framework Convention on Climate Change. (2017b). Report of the Executive Committee of the Warsaw International Mechanism for Loss and Damage associated with Climate Change Impacts. Addendum. Retrieved from: http://FCCC/SB/2017/1/Add.1

UNFCCC SCF. (UNFCCC Standing Committee on Finance) (2016). 2016 Biennial Assessment and Overview of Climate Finance Flows Report. Bonn: United Nations Framework Convention on Climate Change Standing Committee on Finance.

van Asselt, H., Weikmans, R., Roberts, J.T., and Abeysinghe, A. (2016). Transparency of Action and Support under the Paris Agreement. Retrieved from: http://www.eurocapacity.org/downloads/Transparency_in_Paris_Agreement.pdf

Vanhala, L. and Hestbaek, C. (2016). Framing Loss and Damage in the UNFCCC Negotiations: The Struggle over Meaning and the Warsaw International Mechanism. Global Environmental Politics. Retrieved from: http://discovery.ucl.ac.uk/1478385/

Warner, K., Ranger, N., Surminski, S., Arnold, M., Linnnerooth-Bayer, J., Michel-Kerjan, E. ... Herweijer, C. (2009). Adaptation to climate change: Linking disaster risk reduction and insurance. Geneva: United Nations International Strategy for Disaster Reduction Secretariat. Retrieved from: http://riskaward.org/dms/MRS/Documents/Microinsurance/MIC_Agriculture_Bibliography/9654_linki ngdrrinsurance.pdf

Warner, K., Yuzva, K., Zissener, M., Gille, S., Voss, J. and S. Wanczeck (2013). Innovative Insurance Solutions for Climate Change: How to integrate climate risk insurance into a comprehensive climate risk management approach. Report No. 12. Bonn: United Nations University Institute for Environment and Human Security (UNU-EHS). Retrieved from: http://collections.unu.edu/eserv/UNU:1850/pdf11484.pdf

Weikmans, R., \& Roberts, J. T. (2017). The international climate finance accounting muddle: is there hope on the horizon?. Climate and Development, DOI: 10.1080/17565529.2017.1410087.

Weikmans, R., Roberts, J.T., Baum, J., Bustos, M.C., and Durand, A. (2017). Assessing the Credibility of how Climate Adaptation Aid Projects are Categorised. Development in Practice 27 (4): 458-471.

Weingartner, L., Simonet, C. and Caravani, A. Disaster risk insurance and the triple dividend of resilience. Overseas Development Institute, September 2017. Retrieved from: https://www.odi.org/publications/10926-disaster-risk-insurance-and-triple-dividendresilience

Wilcox, R., Kassam, F., Syroka, J., \& Mapfumo, S. (2014). African risk capacity briefing book. Addis Ababa and Rome: African Union and the United Nations World Food Programme. Retrieved from: http://www.africanriskcapacity.org/c/document_library/get_file?uuid=9fb04f73-f7c4-47ea940f- ebe275f55767\&groupId $=350251$ 